BAINY, André Kabke. Prospeç̧ões acerca do atual cenário do conhecimento jurídico: um estudo de caso na opinião de estudantes da faculdade de direito da Universidade Federal de Pelotas/RS. Revista Eletrônica Direito e Política, Programa de Pós-Graduação Stricto Sensu em Ciência Jurídica da UNIVALI, Itajaí, v.11, n.3, 30 quadrimestre de 2016. Disponível em: www.univali.br/direitoepolitica - ISSN 1980-7791.

\title{
PROSPECÇÕES ACERCA DO ATUAL CENÁRIO DO CONHECIMENTO JURÍDICO: UM ESTUDO DE CASO BASEADO NA OPINIÃO DE ESTUDANTES DA FACULDADE DE DIREITO DA UNIVERSIDADE FEDERAL DE PELOTAS/RS
}

PROSPECTIONS ABOUT THE CURRENT SCENARIO OF LEGAL KNOWLEDGE: A CASE STUDY BASED ON LAW SCHOOL OF FEDERAL UNIVERSITY OF PELOTAS STUDENT'S OPINION

André Kabke Bainy

SUMÁRIO: Introdução; 1. Breves incursões sobre o estado d'arte da epistemologia jurídica contemporânea; 2. O que os respondentes pensam sobre isso?; 3. O atual cenário do ensino jurídico: alguns apontamentos; 4 . O papel da doutrina no e para o Direito: uma faca de dois gumes; Considerações finais; Referências das fontes citadas.

\section{RESUMO}

O atual panorama do conhecimento humano tem acarretado inúmeros questionamentos acerca de sua própria validação, produção, reprodução e transmissão, sendo que tais reflexões parecem apontar para a necessidade de se retornar aos fundamentos do próprio conhecimento (questões epistemológicas). Em específico, no caso do Direito, isso igualmente é observado, se considerado que grande parte das discussões jurídicas contemporâneas traz consigo questões relacionadas à própria teoria do Direito (em aspectos como legitimidade e eficácia do Direito, por exemplo). Há, portanto, uma profunda ligação entre "teoria" e "prática". Nesse contexto, o objetivo do presente trabalho ${ }^{2}$ é, servindo de aporte ao posterior (e necessário) aprofundamento teórico da questão, analisar a opinião de acadêmicos da graduação da Faculdade de Direito da Universidade Federal de Pelotas, coletadas por meio de questionários, acerca de questões relacionadas ao conhecimento jurídico, bem como apresentar breves inferências acerca do cenário de ensino-aprendizagem do Direito e do papel da Doutrina para uma possível mudança na produção do pensamento jurídico. Para tanto, foi realizada uma pesquisa quantitativa de caráter estatístico, somando-se à pesquisa bibliográfica adequada de modo a viabilizar a compreensão dos

\footnotetext{
1 Bacharel em Direito pela Universidade Federal de Pelotas (2015). Pelotas, Rio Grande do Sul, Brasil. Advogado. E-mail: andrebainy@hotmail.com

2 o presente trabalho foi extraído, e posteriormente aprofundado, de um capítulo do Trabalho de Conclusão de Curso apresentado junto à Faculdade de Direito da UFPel, sob a orientação do

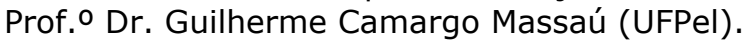


BAINY, André Kabke. Prospecções acerca do atual cenário do conhecimento jurídico: um estudo de caso na opinião de estudantes da faculdade de direito da Universidade Federal de Pelotas/RS. Revista Eletrônica Direito e Política, Programa de Pós-Graduação Stricto Sensu em Ciência Jurídica da UNIVALI, Itajaí, v.11, n.3, 30 quadrimestre de 2016. Disponível em: www.univali.br/direitoepolitica - ISSN 1980-7791.

resultados e elaboração de breves prescrições/inferências. Foi utilizado o método de abordagem indutivo e os métodos procedimentais monográfico e estatístico.

Palavras-chave: Conhecimento Jurídico; Epistemologia; Teoria; Prática, Disciplinas Propedêuticas.

\section{ABSTRACT}

The current landscape of human knowledge has caused many questions about its own validation, production, reproduction and transmission, and these reflections seem to point to the necessity to return to the foundations of knowledge (epistemológica questions). In particular, in the case of Law, it $i$ salso observed, considering that much of the contemporany legal discussions carry issues related to own theory of Law (in aspects such as legitimacy and effectiveness of the Law, for example). Therefore, in Law there is a deep relation between "theory" and "practice". In this context, the objective of this article, serving as a contribution to later (and necessary) theoretical study of the issue, is to analyze the opinion of the studentes of Law School of Federal University of Pelotas, colletcted bay means of questionnaires, about issues related to legal knowledge, and presente brief inferences about the Law's teaching-learning scenario and the role of Doctrine for a possible change in the production of legal thinking. Therefore, it was made a quantitative survey of statistical character, adding to the appropriate bibliographical research in order to facilitate the understanding of the results and preparation of brief prescriptions/inferences. It used the inductive approach method and procedural monographic and statistical methods.

Keywords: Legal Knowledge; Epistemology; Theory, Practice; Propeaedeutical Subjects.

\section{INTRODUÇÃO}

O cenário vivido pelo pensamento contemporâneo aparenta, em caráter geral, uma imersão na crise do próprio conhecimento e de sua produção. Da mesma maneira, de modo específico, essa crise pode ser observada no que se refere ao Direito e ao conhecimento jurídico.

Especialmente desde o Séc. XX inúmeros estudiosos têm buscado explicações pedagógicas, filosóficas, sociais e psicológicas para tais circunstâncias, havendo inegável avanço nas discussões relacionadas à temática. No entanto, justamente por trazer características do próprio ambiente contemporâneo - como a especialidade e a catalogação -, observando-se parte do arcabouço científico 
BAINY, André Kabke. Prospecções acerca do atual cenário do conhecimento jurídico: um estudo de caso na opinião de estudantes da faculdade de direito da Universidade Federal de Pelotas/RS. Revista Eletrônica Direito e Política, Programa de Pós-Graduação Stricto Sensu em Ciência Jurídica da UNIVALI, Itajaí, v.11, n.3, 30 quadrimestre de 2016. Disponível em: www.univali.br/direitoepolitica - ISSN 1980-7791.

produzido, parece ainda haver um hiato entre aquilo que se propõe em termos teóricos da práxis efetivamente observada.

Ilustrando isso que aqui denominamos "hiato", podemos destacar algumas discussões sobre ativismo judicial e judicialização da política (envolvendo a legitimidade do Direito) ou a eficácia dos direitos fundamentais previstos na Constituição Federal (envolvendo a eficácia do Direito). Tais questões parecem ser, na maioria das vezes, travadas em âmbitos particulares e específicos (ramos do direito, como direito constitucional, direito processual, etc.), ocasionando um descolamento das mesmas em relação ao "Direito como um todo" - na integralidade de sua essência.

Ora, se essa inferência apresenta alguma consistência, certo é que tal circunstância pode vir a demonstrar a necessidade de ainda se retornar às questões de fundo do conhecimento em geral e do conhecimento jurídico em específico. Desse modo, para que aquelas discussões acima exemplificadas possam atingir um grau de maturidade, elas devem ser elevadas a um profundo nível teórico, haja vista que as mesmas são, em última análise, problemas da própria Teoria do Direito, tangenciando reflexões acerca do que seja o Direito, do que deva ser o Direito, de como o Direito deve ser interpretado e aplicado, de como o Direito se relaciona com a moral e com a política e de qual é e/ou deve ser o papel do Direito na sociedade contemporânea.

Ocorre que, como já afirmado, o cenário é outro: é o de intensa ruptura entre "teoria" e "prática" do/no Direito. Daí se indaga o porquê de ter havido essa ruptura, bem como de que modo e em que momento isso ocorreu.

Porém antes de se adentrar em discussões dessa envergadura, mostra-se relevante - e mesmo necessário - que sejam colhidos elementos capazes de apresentar o atual cenário do conhecimento jurídico, seja no que tange à sua produção, reprodução, transmissão e aplicação. E é justamente esse o objetivo do presente trabalho: apresentar informações que ilustrem o estado d'arte do conhecimento jurídico contemporâneo. 
BAINY, André Kabke. Prospecções acerca do atual cenário do conhecimento jurídico: um estudo de caso na opinião de estudantes da faculdade de direito da Universidade Federal de Pelotas/RS. Revista Eletrônica Direito e Política, Programa de Pós-Graduação Stricto Sensu em Ciência Jurídica da UNIVALI, Itajaí, v.11, n.3, 30 quadrimestre de 2016. Disponível em: www.univali.br/direitoepolitica - ISSN 1980-7791.

Frequentemente 0 mundo jurídico revela-se intelectualmente preguiçoso: prefere-se o "não pensar" - sob o argumento de que tal atividade "não é da minha alçada", "não é o meu dever", "não tenho competência para tanto" - do que o cogitar, refletir. Ocorre que quem pensa assim acaba deixando de considerar que o "não pensar" propriamente dito já é consequência do uso da logos (razão prática). Ou seja, mesmo que se negue, o "não pensar" já é uma escolha racional e ideológica.

E, nesse contexto, o "não pensar" as coisas do e no Direito se torna ainda mais problemático, na medida em que não é apenas uma forma de manter o status quo epistêmico da ciência jurídica - o que por si só já seria um problema - mas de também não abordar, na maioria das vezes, o cerne das questões problemáticas que afetam diariamente às pessoas, à sociedade, etc.

Algumas das explicações para isso - que serão apresentadas e justificadas ao longo do presente trabalho - apontam para o fato de que, na maior parte das vezes, o profissional do Direito não leva a sério as disciplinas teóricopropedêuticas, seja por não ser incentivado a ter tal postura, seja por não vislumbrar uma "aplicação prática do conhecimento adquirido", seja por não cogitar retorno financeiro e profissional advindos de tal estudo, ou seja, talvez, simplesmente por não ser o tipo de conhecimento exigido na maioria das seleções/provas/concursos da atualidade.

Nesse contexto, e para fins de confirmação de tal hipótese, tentar-se-á obter, por amostragem, por meio da aplicação de questionários, as opiniões de acadêmicos no que concerne à dicotomia "teoria e prática" e à importância das disciplinas propedêuticas na formação de um bacharel em Direito, bem como se fará observações acerca do papel da doutrina nesse emblemático contexto vivido pelo conhecimento jurídico.

Foi realizada, para tanto, uma pesquisa quantitativa de caráter estatístico, de índole prático-teórica essencialmente descritiva, somando-se à pesquisa bibliográfica adequada de modo a viabilizar a compreensão dos resultados e elaboração de breves prescrições/inferências. 
BAINY, André Kabke. Prospeç̧ões acerca do atual cenário do conhecimento jurídico: um estudo de caso na opinião de estudantes da faculdade de direito da Universidade Federal de Pelotas/RS. Revista Eletrônica Direito e Política, Programa de Pós-Graduação Stricto Sensu em Ciência Jurídica da UNIVALI, Itajaí, v.11, n.3, 30 quadrimestre de 2016. Disponível em: www.univali.br/direitoepolitica - ISSN 1980-7791.

Foi utilizado, ademais, o método de abordagem indutivo, haja vista que se pretendeu chegar às "conclusões cujo conteúdo é muito mais amplo do que as premissas nas quais se basearam" ${ }^{3}$. Os métodos procedimentais utilizados, por sua vez, foram os métodos monográfico e estatístico.

\section{BREVES INCURSÕES SOBRE O ESTADO D'ARTE DA EPISTEMOLOGIA JURÍDICA CONTEMPORÂNEA}

A fragmentação da vida humana, nas suas mais variadas esferas, tem impulsionado uma clara busca pelo especialismo ${ }^{4}$. Essa fragmentação tem origem na hipervelocidade da vida contemporânea ${ }^{5}$, onde não tem havido mais espaço para questionamentos de maior solidez e reflexão.

Tal circunstância tem afetado também o Direito, que passou a ser cada vez mais compartimentado, afastando-se de questões relacionadas ao fundamento do próprio fenômeno jurídico. Assim, chegou-se ao diagnóstico: houve uma ruptura incontornável entre "teoria" e "prática".

3 LAKATOS, Eva Maria e MARCONI, Marina de Andrade. Fundamentos da metodologia científica. $2^{\circ}$ ed. São Paulo: Atlas, 1992, p. 47.

${ }^{4}$ A ideia de "especialismo", nos termos aqui utilizados, não se confunde com a de "especialização". Enquanto esta denota a ideia de um estudo especial de certa arte, ciência ou técnica, numa clara intenção de aperfeiçoamento, aquele evidencia a elevação da própria especialização a um patamar de cega justificação de per si - a especialização como um fim em si mesmo, sem importar o contexto e suas justificações.

5 A expressão foi aqui utilizada em referência ao pensamento de Gilles Lipovetsky. Segundo o autor, vivemos num tempo em que "tudo se passa como se tivéssemos ido da era do pós para a era do hiper. Nasce uma nova sociedade moderna. Trata-se não mais de sair do mundo da tradição para aceder à racionalidade moderna, e sim de modernizar a própria modernidade, racionalizar a racionalização - ou seja, na realidade destruir os "arcaísmos" e as rotinas burocráticas, pôr fim à rigidez institucional e aos entraves protecionistas, relocar, privatizar, estimular a concorrência. O voluntarismo do "futuro radiante" foi sucedido pelo ativismo gerencial, uma exaltação da mudança, da reforma, da adaptação, desprovida tanto de um horizonte de esperanças quanto de uma visão grandiosa da história. Por toda a parte, a ênfase é na obrigação do movimento, a hipermudança sem o peso de qualquer visão utópica, ditada pelo imperativo da eficiência e pela necessidade da sobrevivência. Na hipermodernidade, não há escolha, não há alternativa, senão evoluir, acelerar para não ser ultrapassado pela "evolução": o culto da modernização técnica prevaleceu sobre a florificação dos fins e dos ideais (...). Resta saber se, na realidade, isso não significa modernização cega, niilismo técnico-mercantil, processo que transforma a vida em algo sem propósito e sem sentido" (LIPOVETSKY, 2004, p. 56-57, grifo no original). 
BAINY, André Kabke. Prospeç̧ões acerca do atual cenário do conhecimento jurídico: um estudo de caso na opinião de estudantes da faculdade de direito da Universidade Federal de Pelotas/RS. Revista Eletrônica Direito e Política, Programa de Pós-Graduação Stricto Sensu em Ciência Jurídica da UNIVALI, Itajaí, v.11, n.3, 30 quadrimestre de 2016. Disponível em: www.univali.br/direitoepolitica - ISSN 1980-7791.

Essa ruptura não corresponde primordialmente a um problema de técnica e/ou dogmática jurídica, mas, em verdade, pode ser o fator originário de problemas de ordem técnica e/ou dogmática. Aqui é que o caráter epistemológico da discussão ganha ainda mais relevância.

Tal argumento, que é eminentemente teórico-filosófico, acaso verdadeiro, exerce influência sobre todas as áreas relacionadas ao conhecimento jurídico, especialmente quanto ao seu ensino, reprodução e aplicação. Nesse contexto, revela-se oportuno o delineamento do estado d'arte da epistemologia jurídica contemporânea, especificamente quanto aos contextos de produção e reprodução do conhecimento jurídico.

Para tanto, em um primeiro momento será abordada a opinião dos estudantes matriculados nos $1^{0}, 3^{\circ}$ e $6^{\circ}$ anos da Faculdade de Direito da Universidade Federal de Pelotas - UFPel, a qual foi coletada por meio da aplicação de questionários que envolviam aspectos gerais do ensino jurídico, visão global do fenômeno jurídico e opinião acerca das matérias propedêuticas constantes das grades curriculares do curso.

\section{O QUE OS RESPONDENTES PENSAM SOBRE ISSO?}

Conforme acima descrito, a aplicação de questionários para estudantes ${ }^{6}$ da Faculdade de Direito da UFPel teve por objetivo a coleta de dados capazes de informar a opinião dos acadêmicos sobre alguns temas relacionados ao objeto de pesquisa, e, assim, tentar estabelecer um perfil de pensamento/opinião dos mesmos ao longo do curso.

\footnotetext{
6 Vale ressaltar que inicialmente também estava prevista a aplicação de questionários a todos os professores da Faculdade de Direito da UFPel, os quais inclusive vieram a ser confeccionados. Todavia, após a entrega e solicitação pessoal feita a aproximadamente 20 (vinte) professores, apenas 04 (quatro) foram devolvidos com as devidas respostas. Nesse contexto, tendo em vista a exiguidade de tempo para novas tentativas de aplicação, bem como a fim de se evitar situação de eventual constrangimento por conta da insistência por parte do pesquisador, entendeu-se oportuna a desistência na sua coleta.
} 
BAINY, André Kabke. Prospecções acerca do atual cenário do conhecimento jurídico: um estudo de caso na opinião de estudantes da faculdade de direito da Universidade Federal de Pelotas/RS. Revista Eletrônica Direito e Política, Programa de Pós-Graduação Stricto Sensu em Ciência Jurídica da UNIVALI, Itajaí, v.11, n.3, 30 quadrimestre de 2016. Disponível em: www.univali.br/direitoepolitica - ISSN 1980-7791.

Embora a inegável dificuldade ${ }^{7}$ em atingir esse objetivo, entendeu-se que a aplicação dos questionários poderia ser um meio interessante para alcançar elementos quantitativos acerca daquilo que os acadêmicos pensam sobre as disciplinas teóricas e demais aspectos do ensino jurídico, especialmente porque "os processos estatísticos permitem obter, de conjuntos complexos, representações simples e constar se essas verificações simplificadas têm relações entre $\mathrm{si}^{\prime \prime}$, sendo que a estatística deve ser considerada "mais do que apenas um meio de descrição racional; é, também, um método de experimentação e prova, pois é método de análise" ${ }^{\prime 9}$.

Em que pese fosse inviável a aplicação de questionários a todos os respondentes, pretendia-se obter dados de uma forma que realmente espelhassem suas opiniões. Assim, decidiu-se por aplicá-los por amostragem, a qual foi realizada nos seguintes critérios: aplicação, em sala de aula, aos respondentes das turmas do $1^{\circ}$ (41 questionários), $3^{\circ}$ (50 questionários) e $6^{\circ}$ ano (79 questionários), em ambos os turnos (manhã e noite), totalizando 170 questionários aplicados. Destaca-se que a escolha destes parâmetros se deu em virtude de que os dados coletados possivelmente apresentariam alterações do pensamento dos respondentes ao longo do curso. Nesse aspecto, destaca-se que o Curso de Direito da UFPel, diferentemente da maioria das demais universidades, tem 06 (seis) anos de duração.

O questionário (Apêndice $A$ ) é composto por seis perguntas, sendo que três delas (as questões " 1 ", " 2 " e " 6 ") são eminentemente objetivas - visando à escolha por apenas uma resposta - cujas respostas foram quantificadas em porcentagem, enquanto as outras três (questões "3", "4" e "5") avaliativas -

\footnotetext{
${ }^{7}$ Fala-se em "dificuldade" haja vista que a temática abordada nos questionários é permeada por subjetivismos e ideologias das mais variadas espécies - o que certamente influencia nas respostas -, bem como pelo fato de ter sido tarefa extremamente árdua a formulação objetiva de questionamentos (assertivas) que versam sobre conteúdos não objetivos e pela indesejada possibilidade de que a maneira pela qual o questionário foi idealizado e aplicado acabasse por induzir as respostas dos acadêmicos.
}

8 LAKATOS, Eva Maria e MARCONI, Marina de Andrade. Fundamentos da metodologia científica, p. 83.

9 LAKATOS, Eva Maria e MARCONI, Marina de Andrade. Fundamentos da metodologia científica, p. 84 . 
BAINY, André Kabke. Prospecções acerca do atual cenário do conhecimento jurídico: um estudo de caso na opinião de estudantes da faculdade de direito da Universidade Federal de Pelotas/RS. Revista Eletrônica Direito e Política, Programa de Pós-Graduação Stricto Sensu em Ciência Jurídica da UNIVALI, Itajaí, v.11, n.3, 30 quadrimestre de 2016. Disponível em: www.univali.br/direitoepolitica - ISSN 1980-7791.

abordando aspectos como "importância" e "preferência" - cujas respostas foram quantificadas em valores numéricos. As opções de resposta foram elencadas com base naquilo que comumente é utilizado como argumento nos debates jurídicoacadêmicos, bem como por critério de afinidade - especialmente nas perguntas "3" e "4" relativas às disciplinas -, além das próprias percepções do pesquisador.

A questão "1" foi formulada com o objetivo de se apreender o que se passa no imaginário do acadêmico de Direito quando se pensa em "Direito". Nesse sentido, embora intimamente relacionada, a questão não corresponde exatamente à pergunta "o que é o Direito", mas, sim, qual a primeira associação mental feita pelo questionado ao pensar no termo. As respostas foram distribuídas na forma ilustrada pela Tabela 1.

TABELA 1 - Questão "1": Ao pensar em "Direito", o que vem de imediato à sua mente?

\begin{tabular}{|c|c|c|c|c|c|c|}
\hline Referência & Lei & Justiça & Ordem & Estado & Sociedade & Outro \\
\hline 10 ano $(\%)$ & $8(19,5 \%)$ & $13(31,7 \%)$ & $12(29,2 \%)$ & $2(4,8 \%)$ & $6(14,6 \%)$ & - \\
\hline 30 ano (\%) & $12(24 \%)$ & $26(52 \%)$ & $3(6 \%)$ & $4(8 \%)$ & $2(4 \%)$ & $3(6 \%)$ \\
\hline $6^{\circ}$ ano (\%) & $31(39,2 \%)$ & $28(35,4 \%)$ & $3(3,7 \%)$ & $13(16,4 \%)$ & $4(5 \%)$ & - \\
\hline Total (\%) & $51(30 \%)$ & $68(40 \%)$ & $18(10,58 \%)$ & $19(11,17 \%)$ & $12(7,05 \%)$ & $3(1,76 \%)$ \\
\hline
\end{tabular}

Como se verifica dos dados acima discriminados, a maioria dos respondentes dividiu suas respostas entre "lei" e "justiça", o que aponta para a ainda atual relação dicotômica desses conceitos com a ideia de "Direito". Foi justamente no $1^{0}$ ano onde as respostas se diversificaram com mais intensidade, inclusive aparecendo a resposta "ordem" como padrão melhor avaliado do que a opção "lei". Além disso, foi no ano inicial que a alternativa "sociedade" alcançou seu maior percentual. 
BAINY, André Kabke. Prospecções acerca do atual cenário do conhecimento jurídico: um estudo de caso na opinião de estudantes da faculdade de direito da Universidade Federal de Pelotas/RS. Revista Eletrônica Direito e Política, Programa de Pós-Graduação Stricto Sensu em Ciência Jurídica da UNIVALI, Itajaí, v.11, n.3, 30 quadrimestre de 2016. Disponível em: www.univali.br/direitoepolitica - ISSN 1980-7791.

Especificamente quanto ao padrão de resposta "lei", verifica-se o seu aumento considerável ao longo do curso, sendo que o percentual alcançado pelos acadêmicos do $6^{a}$ ano é muito superior àquele respondido pelos respondentes do ano inicial. Daí pode se inferir que há uma concreta mudança de pensamento no transcurso da graduação, a qual pode ser um dos fatores a justificar uma visão (com a consequente compreensão, aplicação, ensino, etc.) legalista do fenômeno jurídico.

No entanto, inferência similar não pode ser feita em relação à alternativa "justiça". Isso porque, embora essa opção tenha atingido altos percentuais em todas as turmas questionadas, o ano que melhor a avaliou corresponde ao 30 ano - ou seja, o intermediário. Nesse contexto, não há como se falar em "progresso", "regresso" ou "manutenção" desse padrão de respostas, cabendo, eventualmente, uma análise mais específica para se compreender se foi um resultado específico em relação ao $3^{\circ}$ ano de 2015 - o que ensejaria uma análise comportamental - ou se a metade do curso é um período em que a temática da justiça e suas aporias vem à tona com maior força - o que poderia trazer repercussões à análise epistemológica. No momento, a presente pesquisa se contenta com a descrição dos dados coletados.

Já a questão "2" foi formulada com o objetivo de se apreender se o argumento utilizado como problema de pesquisa - qual seja o de que a maioria dos problemas do Direito do Direito têm raízes essencialmente teóricas/propedêuticas, motivo pelo qual a separação dicotômica entre "teoria" e "práxis" seria indevida e revelaria um problema epistemológico do conhecimento jurídico - teria amparo no pensamento dos acadêmicos. Em outras palavras, a questão objetivou verificar o que os respondentes pensam a respeito do problema de pesquisa.

As respostas foram distribuídas na forma ilustrada pela Tabela 2 . 
BAINY, André Kabke. Prospecções acerca do atual cenário do conhecimento jurídico: um estudo de caso na opinião de estudantes da faculdade de direito da Universidade Federal de Pelotas/RS. Revista Eletrônica Direito e Política, Programa de Pós-Graduação Stricto Sensu em Ciência Jurídica da UNIVALI, Itajaí, v.11, n.3, 30 quadrimestre de 2016. Disponível em: www.univali.br/direitoepolitica - ISSN 1980-7791.

\section{TABELA 2 - Questão "2": Ao pensar sobre os problemas jurídicos, para você qual é o principal fator determinante para o surgimento/perpetuação de tais problemas?}

\begin{tabular}{|c|c|c|c|c|c|c|}
\hline Referência & Letra "a" & Letra "b" & Letra "c" & Letra "d" & Letra "e" & Letra "f"' \\
\hline 10 ano (\%) & $15(36,5 \%)$ & $1(2,4 \%)$ & $2(4,8 \%)$ & $4(9,7 \%)$ & $12(29,2 \%)$ & $7(17 \%)$ \\
\hline $3^{\circ}$ ano (\%) & $05(10 \%)$ & $3(6 \%)$ & $2(4 \%)$ & $3(6 \%)$ & $22(44 \%)$ & $15(30 \%)$ \\
\hline $6^{\circ}$ ano $(\%)$ & $22(27,8 \%)$ & $1(1,2 \%)$ & $3(3,7 \%)$ & $3(3,7 \%)$ & $34(43 \%)$ & $16(20,2 \%)$ \\
\hline Total (\%) & $42(24,7 \%)$ & $5(2,9 \%)$ & $7(4,1 \%)$ & $10(5,8 \%)$ & $68(40 \%)$ & $38(22,3 \%)$ \\
\hline
\end{tabular}

Observando esses dados, verifica-se a aparente contradição nas respostas dadas pelos respondentes do $1^{\circ}$ ano, haja vista que na questão "1" a resposta "lei" foi apenas a terceira mais votada, circunstância que não impediu que a maioria dos respondentes do ano inicial entendessem que o fator determinante para o surgimento/perpetuação dos problemas jurídicos fosse a baixa qualidade legislativa (alternativa prevista na letra "a" da questão " 2 ").

A alternativa " $b$ ", que atribuía tais problemas à má formação dos profissionais do Direito, foi a globalmente menos votada. Disso é possível se inferir que na visão dos respondentes não há um nexo de causalidade necessário entre o cenário de problemas que permeia o ambiente jurídico e a relação ensino/aprendizagem nas faculdades de Direito do país. Embora essa opção não esteja diretamente ligada aos argumentos defendidos na presente pesquisa, a baixa votação não deixou de ser surpreendente, especialmente ao ter-se em vista a extensa bibliografia produzida sobre o tema no Brasil e as constantes críticas formuladas ao modelo de ensino superior aqui vivenciado (em específico, o ensino jurídico).

A opção constante da letra " $e$ ", que foi a globalmente mais votada, versava sobre "a falta de compreensão do fenômeno jurídico como um todo, o que leva à desconexão do Direito com outras áreas da vida". De certa forma esse resultado mostrou-se surpreendente, na medida em que essa alternativa, juntamente com a letra "f" - igualmente bem votada -, é a opção que mais se enquadra na perspectiva teórica defendida na presente pesquisa. 
BAINY, André Kabke. Prospecções acerca do atual cenário do conhecimento jurídico: um estudo de caso na opinião de estudantes da faculdade de direito da Universidade Federal de Pelotas/RS. Revista Eletrônica Direito e Política, Programa de Pós-Graduação Stricto Sensu em Ciência Jurídica da UNIVALI, Itajaí, v.11, n.3, 30 quadrimestre de 2016. Disponível em: www.univali.br/direitoepolitica - ISSN 1980-7791.

Nesse contexto, deve ser admitido que o posicionamento dos acadêmicos respondentes - ao menos tomando por base a maioria das respostas - vai ao encontro daquilo aqui defendido acerca da necessidade de uma contínua reflexão sobre o fenômeno jurídico, sua relação com outras áreas da vida e sociedade.

As questões "3" e "4", por sua vez, foram formuladas com o intuito de se apreender, respectivamente a opinião dos respondentes quanto à importância e preferência das disciplinas que compõe o currículo do ensino jurídico.

Ambas as questões têm alternativas de respostas idênticas, as quais contêm grupos de disciplinas que foram organizados por uma análise de afinidade existente entre elas, bem como para facilitar as respostas dos respondentes de modo a não torná-las tão extensas. Contudo, foram formuladas de maneira diferente das questões " 1 " e " 2 ": no lugar de se escolher apenas uma resposta que melhor representasse sua opinião, nas questões " 3 " e "4" os respondentes deveriam assinalar (valorar/ranquear) todas as alternativas ${ }^{10}$.

As respostas da questão 3 foram distribuídas na forma ilustrada pela Tabela 3 .

TABELA 3 - Questão "3": Dentre as seguintes disciplinas que compõe o currículo do ensino jurídico, estabeleça a ordem de importância dos grupos abaixo ("1" para a mais importante até "9" para a menos importante).

\begin{tabular}{|c|c|c|c|c|c|c|c|c|c|}
\hline Referência & $\mathbf{A}$ & B & C & D & E & $\mathbf{F}$ & G & $\mathbf{H}$ & I \\
\hline $\begin{array}{c}1^{\circ} \text { ano } \\
\text { (total/41) }\end{array}$ & $\begin{array}{c}139 \\
(3,3)\end{array}$ & $\begin{array}{c}192 \\
(4,6)\end{array}$ & $\begin{array}{c}170 \\
(4,1)\end{array}$ & $\begin{array}{c}209 \\
(5,1)\end{array}$ & $\begin{array}{c}184 \\
(4,4)\end{array}$ & $\begin{array}{c}195 \\
(4,7)\end{array}$ & $\begin{array}{c}179 \\
(4,3)\end{array}$ & $\begin{array}{l}236 \\
(5,7)\end{array}$ & $\begin{array}{c}278 \\
(6,7)\end{array}$ \\
\hline $\begin{array}{c}3^{\circ} \text { ano } \\
\text { (total/50) }\end{array}$ & $\begin{array}{c}169 \\
(3,3)\end{array}$ & $\begin{array}{l}206 \\
(4,2)\end{array}$ & $\begin{array}{c}260 \\
(5,2)\end{array}$ & $\begin{array}{c}294 \\
(5,8)\end{array}$ & $\begin{array}{l}211 \\
(4,2)\end{array}$ & $\begin{array}{c}268 \\
(5,3)\end{array}$ & $\begin{array}{c}227 \\
(4,5)\end{array}$ & $\begin{array}{l}251 \\
(5)\end{array}$ & $\begin{array}{c}336 \\
(6,7)\end{array}$ \\
\hline $\begin{array}{c}6^{\circ} \text { ano } \\
\text { (total/79) }\end{array}$ & $\begin{array}{l}194 \\
(2,4)\end{array}$ & $\begin{array}{c}302 \\
(3,8)\end{array}$ & $\begin{array}{l}318 \\
(4)\end{array}$ & $\begin{array}{c}385 \\
(4,8)\end{array}$ & $\begin{array}{c}362 \\
(4,5)\end{array}$ & $\begin{array}{l}477 \\
(6)\end{array}$ & $\begin{array}{c}371 \\
(4,6)\end{array}$ & $\begin{array}{c}447 \\
(5,6)\end{array}$ & $\begin{array}{l}553 \\
(7)\end{array}$ \\
\hline $\begin{array}{c}\text { Total } \\
\text { (total/170) }\end{array}$ & $\begin{array}{c}502 \\
(2,9)\end{array}$ & $\begin{array}{c}700 \\
(4,1)\end{array}$ & $\begin{array}{l}748 \\
(4,4)\end{array}$ & $\begin{array}{l}888 \\
(5,2)\end{array}$ & $\begin{array}{c}757 \\
(4,4)\end{array}$ & $\begin{array}{c}940 \\
(5,5)\end{array}$ & $\begin{array}{l}777 \\
(4,5)\end{array}$ & $\begin{array}{c}934 \\
(5,4)\end{array}$ & $\begin{array}{l}1167 \\
(6,8)\end{array}$ \\
\hline
\end{tabular}

10 As alternativas das questões " 3 " e "4" eram as seguintes: "A" - Direito constitucional, administrativo, financeiro e tributário; "B" - Direito Civil, Consumidor e Empresarial; "C" - Direito Processual Civil e Direito Processual Penal; "D" - Direito do Trabalho e Direito Previdenciário; " $E$ " - Direito Penal e Criminologia; "F" - Laboratório de Prática Jurídica e Serviço de Assistência Judiciária; "G" - Introdução ao Direito, Filosofia do Direito e Hermenêutica; "H" - Teoria do Estado, Poder e Direito/Sociologia/Antropologia; "I" - Psicologia Jurídica. 
BAINY, André Kabke. Prospecções acerca do atual cenário do conhecimento jurídico: um estudo de caso na opinião de estudantes da faculdade de direito da Universidade Federal de Pelotas/RS. Revista Eletrônica Direito e Política, Programa de Pós-Graduação Stricto Sensu em Ciência Jurídica da UNIVALI, Itajaí, v.11, n.3, 30 quadrimestre de 2016. Disponível em: www.univali.br/direitoepolitica - ISSN 1980-7791.

Conforme acima afirmado, a questão foi desenvolvida visando à atribuição das menores notas às disciplinas "mais importantes" e das maiores notas às disciplinas "menos importantes" na visão dos respondentes.

Nesse contexto, pelos dados coletados verifica-se novamente a falta de homogeneidade nas respostas obtidas, haja vista que, ao menos aparentemente, não houve uma alteração gradual das notas entre cada uma das turmas (seja em aumento ou diminuição). Da mesma maneira, destaca-se que nenhuma das opções alcançou a nota máxima (nota "9", correspondente à disciplina de "menor importância" dentre as alternativas), tampouco alcançou a nota mínima (nota "1").

Embora tenha se verificado tal circunstância, igualmente é possível se inferir que, ao se considerar as opiniões globais de cada uma das turmas questionadas, houve unanimidade nas escolhas das disciplinas de maior e menor importância, sendo justamente esses os únicos campos onde tal fato é verificado.

Com efeito, o campo de disciplinas do grupo " $\mathrm{A}$ ", do chamado "direito público11" - Direito Constitucional, Direito Administrativo, Direito Financeiro e Direito Tributário -, foi o mais bem votado em cada uma das turmas, que o consideraram como o mais importante no currículo do ensino jurídico - o que pode ser explicado pelo contexto neoconstitucionalista vivido no atual cenário jurídico do Direito.

Em lado diametralmente oposto, o grupo "I", por sua vez, composto apenas de uma disciplina (Psicologia Jurídica), foi aquele que atingiu unanimemente a pior pontuação. Acerca disso, vale ressaltar uma consideração metodológica que só veio à tona após a aplicação e levantamento dos questionários: o grupo "I" foi o único composto por apenas uma disciplina, circunstância que pode ter influenciado na sua baixa votação. De todo modo, não há como se duvidar do baixo prestígio que a disciplina de Psicologia Jurídica goza no ambiente acadêmico do Direito.

${ }^{11}$ A expressão foi marcada entre aspas em razão de não se concordar com referida classificação. Apenas foi feita referência a ela para fins de maior objetividade/didatismo. 
BAINY, André Kabke. Prospecções acerca do atual cenário do conhecimento jurídico: um estudo de caso na opinião de estudantes da faculdade de direito da Universidade Federal de Pelotas/RS. Revista Eletrônica Direito e Política, Programa de Pós-Graduação Stricto Sensu em Ciência Jurídica da UNIVALI, Itajaí, v.11, n.3, 30 quadrimestre de 2016. Disponível em: www.univali.br/direitoepolitica - ISSN 1980-7791.

Os grupos que tiveram a menor variação de nota entre as diferentes turmas foram os grupos "E" (Direito Penal e Criminologia) e "G" (Introdução ao Direito, Filosofia do Direito e Hermenêutica), alcançando no somatório total terceiro e quinto lugares, respectivamente.

Especificamente no que tange ao grupo "G", mesmo ao se considerar que houve pequena variância entre as turmas, verifica-se um padrão de declínio nas notas, sendo justamente nas turmas do $6^{\circ}$ ano que esse grupo alcançou a pior avaliação. Não obstante tal decréscimo, chama a atenção o fato desse grupo ter sido melhor avaliado do que, por exemplo, o grupo " $D$ " - que cuida de disciplinas precipuamente práticas, como o Direito do Trabalho e Direito Previdenciário.

Já as respostas da questão 4 foram distribuídas na forma ilustrada pela Tabela 4 .

TABELA 4 - Questão "4": Dentre as seguintes disciplinas que compõe o currículo do ensino jurídico, estabeleça a ordem de preferência dos grupos abaixo ("1" para a mais importante até "9" para a menos importante).

\begin{tabular}{|c|c|c|c|c|c|c|c|c|c|}
\hline Referência & $\mathbf{A}$ & B & C & D & E & $\mathbf{F}$ & G & $\mathbf{H}$ & $\mathbf{I}$ \\
\hline $\begin{array}{c}1^{\circ} \text { ano } \\
\text { (total/41) }\end{array}$ & $\begin{array}{c}155 \\
(3,7)\end{array}$ & $\begin{array}{c}177 \\
(4,3)\end{array}$ & $\begin{array}{c}171 \\
(4,1)\end{array}$ & $\begin{array}{c}217 \\
(5,2)\end{array}$ & $\begin{array}{l}168 \\
(4)\end{array}$ & $\begin{array}{l}208 \\
(5)\end{array}$ & $\begin{array}{c}201 \\
(4,9)\end{array}$ & $\begin{array}{c}234 \\
(5,7)\end{array}$ & $\begin{array}{c}274 \\
(6,6)\end{array}$ \\
\hline $\begin{array}{c}3^{\circ} \text { ano } \\
\text { (total/50) }\end{array}$ & $\begin{array}{c}222 \\
(4,4)\end{array}$ & $\begin{array}{c}229 \\
(4,5)\end{array}$ & $\begin{array}{l}259 \\
(5,1)\end{array}$ & $\begin{array}{c}283 \\
(5,6)\end{array}$ & $\begin{array}{c}142 \\
(2,8)\end{array}$ & $\begin{array}{c}272 \\
(5,4)\end{array}$ & $\begin{array}{c}268 \\
(3,3)\end{array}$ & $\begin{array}{c}261 \\
(5,5)\end{array}$ & $\begin{array}{l}279 \\
(5,5)\end{array}$ \\
\hline $\begin{array}{c}6^{\circ} \text { ano } \\
\text { (total/79) }\end{array}$ & $\begin{array}{l}288 \\
(3,6)\end{array}$ & $\begin{array}{c}310 \\
(3,9)\end{array}$ & $\begin{array}{c}311 \\
(3,9)\end{array}$ & $\begin{array}{c}391 \\
(4,9)\end{array}$ & $\begin{array}{c}292 \\
(3,6)\end{array}$ & $\begin{array}{l}475 \\
(6)\end{array}$ & $\begin{array}{l}427 \\
(5,4)\end{array}$ & $\begin{array}{c}471 \\
(5,9)\end{array}$ & $\begin{array}{l}503 \\
(6,3)\end{array}$ \\
\hline $\begin{array}{c}\text { Total } \\
\text { (total/170) }\end{array}$ & $\begin{array}{l}665 \\
(3,9)\end{array}$ & $\begin{array}{l}716 \\
(4,2)\end{array}$ & $\begin{array}{l}741 \\
(4,3)\end{array}$ & $\begin{array}{c}891 \\
(5,2)\end{array}$ & $\begin{array}{c}602 \\
(3,5)\end{array}$ & $\begin{array}{l}955 \\
(5,6)\end{array}$ & $\begin{array}{l}896 \\
(5,2)\end{array}$ & $\begin{array}{l}966 \\
(5,6)\end{array}$ & $\begin{array}{l}1056 \\
(6,2)\end{array}$ \\
\hline
\end{tabular}

O objetivo em elaborar essa questão foi o de tentar se separar as preferências individuais dos acadêmicos daquilo que eles de fato pensam ser importantes. Obviamente, não se cogitou exigir completa neutralidade dos respondentes no preenchimento das respostas - haja vista ser provável que os gostos individuais também pudessem interferir em suas opiniões quanto à "importância" das disciplinas -, mas entendeu-se que, uma vez que as questões fossem elaboradas dessa forma, os pesquisados poderiam se sentir mais livres para reflexão e 
BAINY, André Kabke. Prospecções acerca do atual cenário do conhecimento jurídico: um estudo de caso na opinião de estudantes da faculdade de direito da Universidade Federal de Pelotas/RS. Revista Eletrônica Direito e Política, Programa de Pós-Graduação Stricto Sensu em Ciência Jurídica da UNIVALI, Itajaí, v.11, n.3, 30 quadrimestre de 2016. Disponível em: www.univali.br/direitoepolitica - ISSN 1980-7791.

resposta. E da análise dos resultados obtidos, verifica-se que isso de fato ocorreu.

Diferentemente do que ocorreu na "3", a questão ora analisada não obteve unanimidade em nenhuma das alternativas. O grupo "I", por exemplo, embora também tenha tido a pior pontuação global na análise de preferência dos acadêmicos, não foi o que recebeu a pior avaliação entre os respondentes do 30 ano - a qual ficou a cargo do grupo "D".

Da mesma forma, verifica-se que a questão "4" diferenciou-se da anterior quanto ao grupo de disciplinas que alcançou o status de "preferido". Isso porque o grupo " $A$ ", que havia sido o melhor avaliado na questão anterior, alcançou a segunda colocação global na ordem de preferência dos respondentes respondentes, ao passo que o grupo "E", que havia sido avaliado apenas na terceira colocação na ordem de importância, recebeu com considerável margem de diferença a melhor colocação no quesito "preferência". De tal fato é possível se depreender a forte inclinação dos respondentes em relação ao Direito Penal e à Criminologia.

As disciplinas propedêuticas constantes do grupo " $G$ ", que, conforme acima descrito, haviam sido bem avaliadas, apresentaram queda em seu índice de avaliação, motivo pelo qual pode se inferir que os acadêmicos de certa forma compreendem a importância dessas disciplinas, embora as mesmas não sejam tão agradáveis aos seus gostos pessoais.

Embora o teor desses apontamentos, vale destacar que novamente nenhuma das alternativas chegou perto de alcançar as pontuações " 9 " e " 1 "- que indicariam, respectivamente, a pior e a melhor avaliação possível -, o que denota a homogeneidade nas avaliações.

A questão " 5 " foi formulada, ainda no sistema de valoração das alternativas, para o fim de se apreender a opinião dos respondentes a respeito das práticas pedagógicas existentes no âmbito da Faculdade de Direito da UFPel.

As respostas da questão 5 foram distribuídas na forma ilustrada pela Tabela 5 . 
BAINY, André Kabke. Prospecções acerca do atual cenário do conhecimento jurídico: um estudo de caso na opinião de estudantes da faculdade de direito da Universidade Federal de Pelotas/RS. Revista Eletrônica Direito e Política, Programa de Pós-Graduação Stricto Sensu em Ciência Jurídica da UNIVALI, Itajaí, v.11, n.3, 30 quadrimestre de 2016. Disponível em: www.univali.br/direitoepolitica - ISSN 1980-7791.

TABELA 5 - Questão "5": Dentre as seguintes atividades educacionais possíveis, estabeleça a ordem de importância ("1" para a mais importante até "9" para a menos importante).

\begin{tabular}{ccccccc}
\hline Referência & Ensino & Pesquisa & Extensão & SAJ & Estágio & $\begin{array}{c}\text { Eventos } \\
\text { etc. }\end{array}$ \\
\hline $\mathbf{1 0}^{\mathbf{0}}$ ano (total/41) & $84(2)$ & $124(3,1)$ & $183(4,4)$ & $123(3)$ & $131(3,1)$ & $187(4,5)$ \\
$\mathbf{3}^{\mathbf{0}}$ ano (total/50) & $103(2)$ & $185(3,7)$ & $169(3,3)$ & $154(3)$ & $165(3,3)$ & $256(5,1)$ \\
$\mathbf{6}^{\mathbf{0}}$ ano (total/79) & $147(1,8)$ & $236(2,9)$ & $310(3,9)$ & $279(3,5)$ & $244(3)$ & $403(5,1)$ \\
Total (total/170) & $334(1,9)$ & $545(3,2)$ & $662(3,8)$ & $556(3,2)$ & $540(3,1)$ & $846(4,9)$ \\
\hline
\end{tabular}

Conforme se verifica, a melhor colocação foi atribuída de modo praticamente unânime à alternativa "Ensino", o que demonstra o valor dado pelos acadêmicos às aulas expositivas - que correspondem à regra quase absoluta das aulas ministradas ao longo do curso.

Por outro lado, a opção que sofreu maior desvalorização foi aquela relacionada à participação em eventos, palestras, congressos, etc., recebendo as piores avaliações em todas as turmas questionadas.

Em relação às demais opções houve uma pequena diferença de pontuação entre cada uma delas, sendo possível se inferir a importância dada à prática processual no âmbito do aprendizado jurídico - haja vista tanto a opção do "Serviço de Assistência Judiciária" quanto a opção "estágio" terem sido bem avaliadas -, bem como à alternativa "pesquisa", que especialmente no $6^{\circ}$ ano apresentou uma exímia avaliação.

A última questão constante dos questionários, cujo método retornou ao sistema de "uma única resposta possível", foi elaborada com a finalidade de se apreender a opinião dos respondentes a respeito das justificativas para que as disciplinas propedêuticas sejam consideradas importantes.

Nesse contexto, e juntamente com a questão " 2 ", essa é a questão que mais se aproxima do objeto de pesquisa aqui delineado.

As respostas da questão 6 foram distribuídas na forma ilustrada pela Tabela 6 . 
BAINY, André Kabke. Prospecções acerca do atual cenário do conhecimento jurídico: um estudo de caso na opinião de estudantes da faculdade de direito da Universidade Federal de Pelotas/RS. Revista Eletrônica Direito e Política, Programa de Pós-Graduação Stricto Sensu em Ciência Jurídica da UNIVALI, Itajaí, v.11, n.3, 30 quadrimestre de 2016. Disponível em: www.univali.br/direitoepolitica - ISSN 1980-7791.

TABELA 6 - Questão "6": Na sua opinião, as disciplinas propedêuticas (especificamente Introdução ao Direito, Filosofia do Direito e Hermenêutica) são importantes porque:

\begin{tabular}{cccccc}
\hline Referência & A & B & C & D & E \\
\hline $\mathbf{1 0}^{\mathbf{0}}$ ano (\%) & - & $1(2,5 \%)$ & $3(7,3 \%)$ & $37(90,2 \%)$ & - \\
$\mathbf{3}^{\mathbf{0}}$ ano (\%) & $2(4 \%)$ & $8(16 \%)$ & $14(28 \%)$ & $23(46 \%)$ & $3(6 \%)$ \\
$\mathbf{6}^{\mathbf{0}}$ ano (\%) & $2(2,5 \%)$ & $15(18,9)$ & $10(12,6 \%)$ & $49(62 \%)$ & $3(3,7 \%)$ \\
Total (\%) & $4(2,3 \%)$ & $24(14,1 \%)$ & $27(15,8 \%)$ & $109(64,1 \%)$ & $6(3,5 \%)$ \\
\hline
\end{tabular}

Analisando os dados, verifica-se que as respostas do $3^{\circ}$ ano denotam certo grau de "ceticismo" dos pesquisados em relação às disciplinas propedêuticas, haja vista que foi nessa turma que as alternativas "A" ("passaram a ser exigidas em concursos públicos/exame da $O A B$ ") e "E" ("não são importantes") alcançaram sua maior avaliação. Em todo caso, certo é que essas opções correspondem à opinião de uma minoria.

A alternativa que obteve o maior percentual de respostas foi a " $D$ ", que atribuía a importância das propedêuticas ao fato de que elas "aumentam a capacidade de compreensão do próprio Direito e do mundo como um todo". A aceitação dessa opção foi tamanha a ponto das respostas do $1^{\circ}$ ano alcançarem o surpreendente percentual de $90,2 \%$.

As opções "B" ("dão ao jurista um espírito crítico") e "C" ("aumentam o senso de humanidade e/ou justiça") também foram bem pontuadas, especialmente nos $3 \circ$ e $6^{\circ}$ anos.

Como já afirmado, a decisão por incluir essa questão se fundamentou no interesse em se compreender qual a opinião dos acadêmicos acerca das propedêuticas, dado que ganharia relevância na medida em que aqui tem se discutido a necessidade de reafirmação da importância das disciplinas teóricas do Direito, especialmente em razão da imprescindibilidade das discussões epistemológicas para a adoção de um conhecimento jurídico capaz de enfrentar de forma coerente e sólida os problemas "práticos" do Direito. 
BAINY, André Kabke. Prospecções acerca do atual cenário do conhecimento jurídico: um estudo de caso na opinião de estudantes da faculdade de direito da Universidade Federal de Pelotas/RS. Revista Eletrônica Direito e Política, Programa de Pós-Graduação Stricto Sensu em Ciência Jurídica da UNIVALI, Itajaí, v.11, n.3, 30 quadrimestre de 2016. Disponível em: www.univali.br/direitoepolitica - ISSN 1980-7791.

E, nesse contexto, as respostas - que demonstraram que a opinião da maioria dos respondentes vai ao encontro daquilo já adiantado e defendido na introdução do presente trabalho - mostram-se deveras surpreendentes.

\section{O ATUAL CENÁRIO DO ENSINO JURÍDICO: ALGUNS APONTAMENTOS}

O debate acerca da qualidade do ensino jurídico tem sido frequente, especialmente por conta da proliferação das instituições de ensino superior que o Brasil tem experimentado ${ }^{12}$.

As discussões são, em regra, pautadas por críticas à mercantilização do ensino jurídico e à adoção de métodos simplificados de ensino, semelhantes a dos cursos preparatórios para concursos e Exames da OAB. Também é comum a elaboração de críticas ao atual modelo de ensino jurídico quanto ao seu papel conservador (pouco inovador), mantenedor do status quo jurídico-social.

A temática inclusive ganhou força no âmbito da Ordem dos Advogados do Brasil que já havia participado das discussões que culminaram na publicação da Portaria MEC $n^{\circ} 1.886 / 94$, responsável por instituir as diretrizes curriculares e o conteúdo mínimo dos cursos jurídicos no Brasil -, que institucionalizou a Comissão Nacional de Educação Jurídica, responsável pelo lançamento de relatórios, propostas e outras publicações concernentes à Educação Jurídica. Dentre essas publicações, destaca-se a coleção OAB Ensino Jurídico: Balanço de uma experiência, a qual teve por objetivo a elaboração de propostas "para a formulação de uma 'jus pedagogia' que seria, noutras palavras, a arte e a ciência de 'ensinar direito o Direito'"13.

\footnotetext{
12 Nesse sentido, notícia extraída do portal da Ordem dos Advogados do Brasil aponta para o fato de que o país, sozinho, tem mais faculdades de Direito que todos os demais países juntos. Disponível em: <http://www.oab.org.br/noticia/20734/brasil-sozinho-tem-mais-faculdades-dedireito-que-todos-os-paises>. Acesso em: 25 set. 2015, às 16h04min.

13 ORDEM DOS ADVOGADOS DO BRASIL. OAB Ensino Jurídico: balanço de uma experiência. Brasília: OAB, 2000.
} 
BAINY, André Kabke. Prospecções acerca do atual cenário do conhecimento jurídico: um estudo de caso na opinião de estudantes da faculdade de direito da Universidade Federal de Pelotas/RS. Revista Eletrônica Direito e Política, Programa de Pós-Graduação Stricto Sensu em Ciência Jurídica da UNIVALI, Itajaí, v.11, n.3, 30 quadrimestre de 2016. Disponível em: www.univali.br/direitoepolitica - ISSN 1980-7791.

Ocorre que muitas das críticas acabam se limitando a uma análise ideológica da conjuntura jurídico-educacional - o que não é, por si só, um problema, mas não deixa de ser uma análise insuficiente - ou uma generalização simplista, que normalmente busca atribuir a responsabilidade de forma nominal na tentativa de encontrar culpados - fato que pouco contribui para uma reflexão sólida , coerente e integral do Direito.

Nesse contexto, embora se reconheça a problemática situação que o ensino jurídico experimenta, bem como a relevância dos argumentos que vem sendo utilizados, o presente estudo entende que esse debate é tangencial - não central - aos grandes problemas do Direito.

Isso porque a precariedade do ensino jurídico e os demais problemas correlatos indicam, antes de uma causa, o sintoma de um contexto problemático maior e anterior.

É necessária uma análise e adequação das práticas pedagógicas. Uma reformulação curricular também parece fundamental para que a qualidade do ensino jurídico seja elevada.

Contudo, mais do que na relação de ensino-aprendizagem - que obviamente deve fazer parte de uma análise epistemológica comprometida -, a questão gira em torno da reflexão acerca das condições de validade, produção, reprodução e aplicação do conhecimento jurídico, bem como dos seus limites e do seu papel no âmbito maior da vida humana. Se ao contrário fosse, qualquer reformulação no ensino do Direito se limitaria a aspectos ideológicos.

Ao longo do estudo, de modo a se introduzir o argumento ora utilizado, vem sendo defendida a ideia de que o Direito passa por um momento de crise no atual estágio histórico, especialmente por não estar mais dando conta de responder de forma legítima e eficaz os anseios de uma sociedade que tanto o prestigia. Vem sendo defendida, além disso, a ideia de que essa crise pode ser observada em várias outras discussões "menores", as quais não raras as vezes 
BAINY, André Kabke. Prospecções acerca do atual cenário do conhecimento jurídico: um estudo de caso na opinião de estudantes da faculdade de direito da Universidade Federal de Pelotas/RS. Revista Eletrônica Direito e Política, Programa de Pós-Graduação Stricto Sensu em Ciência Jurídica da UNIVALI, Itajaí, v.11, n.3, 30 quadrimestre de 2016. Disponível em: www.univali.br/direitoepolitica - ISSN 1980-7791.

se encerram no seu próprio nicho de debate, e que por isso deixa de levar em conta a complexidade da vida e do próprio Direito.

Assim, na linha de raciocínio aqui desenvolvida, qualquer pretensão de reforma do ensino jurídico, se levada a efeito de maneira exclusivista, não passará de um analgésico útil apenas à amenização do sintoma, porém insuficiente à cura propriamente dita do problema. Em lado oposto, uma vez sendo estabelecidos pontos de partida sólidos no âmbito teórico-metodológico, a forma como os conteúdos serão ensinados poderá se adequar à coerência, à racionalidade e ao efetivo papel do Direito na vida em sociedade.

Reforça-se, ainda mais, a ideia de que corresponde a um debate precipuamente epistemológico.

\section{O PAPEL DA DOUTRINA NO E PARA O DIREITO: UMA FACA DE DOIS GUMES}

A doutrina, que corresponde à produção bibliográfico-científica de estudiosos de determinada especialidade jurídica, tem papel importante tanto na formulação quanto na atualização das normas jurídicas. Mesmo assim, há infindável discussão acerca dela poder ser considerada fonte do Direito ou não. Nesse sentido, Falcón y Tella bem contextualiza o debate e sustenta, de forma bastante sólida, o seu ponto de vista pelo não enquadramento enquanto fonte de produção do Direito afirmando que:

Historicamente, a doutrina científica gozou de um grande prestígio e até de força vinculante. Foi o caso, por exemplo, dos "prudentes", no Direito romano, que deram nome à jurisprudência, entendida como autêntica ciência (...). Atualmente, (...) a doutrina científica não é fonte do Direito, mas sim meio para conhecê-lo, fonte não de criação, mas sim de mero conhecimento. A razão é que a mesma não procede de competência, "imperium" ou poder soberano, mas sim da ciência ou julgamento pessoal dos juristas. Não tem, pois, mais valor que o da autoridade científica de seu autor e a força de seus argumentos. É a distinção existente 
BAINY, André Kabke. Prospecções acerca do atual cenário do conhecimento jurídico: um estudo de caso na opinião de estudantes da faculdade de direito da Universidade Federal de Pelotas/RS. Revista Eletrônica Direito e Política, Programa de Pós-Graduação Stricto Sensu em Ciência Jurídica da UNIVALI, Itajaí, v.11, n.3, 30 quadrimestre de 2016. Disponível em: www.univali.br/direitoepolitica - ISSN 1980-7791.

entre os conceitos de competência e autoridade. A primeira implica uma supremacia imposta de fora, por méritos distintos da valia intrínseca. A autoridade, pelo contrário, não se apoia na força, mas sim no prestígio ${ }^{14}$.

Afora a solidez desse entendimento, é inegável que a importância da doutrina para o Direito é extrema.

É através dela que fenômeno jurídico pode ser compreendido de forma coerente e que a efetividade do Direito pode ser analisada, por exemplo. Ademais, inovações legislativas mostram-se muito mais producentes quando precedidas de discussões entre autores comprometidos com determinada disciplina (em específico) e com o próprio Direito (em geral). Ou seja, a profundidade da técnica jurídica imprescinde de uma doutrina qualificada.

Mas não há que se confundir doutrina com ciência do Direito: embora a segunda contemple a primeira, esta não se reduz àquela.

A doutrina, em regra, visa ao estudo dogmático (não zetético ${ }^{15}$ ) de determinada disciplina jurídica. E o estudo dogmático, para assim ser considerado, depende da adoção de certas premissas (as quais são resultantes de uma discussão) como vinculantes, motivo pelo qual "ao contrário das disciplinas zetéticas, cujas questões são infinitas, as dogmáticas tratam de questões finitas"16.

A adoção de dogmas não parece ser um problema por si só - especialmente porque o Direito trabalha com institutos (ficções), que em muito dependem desses Dogmas.

No entanto, somando-se a adoção de critérios dogmáticos de maneira acrítica à cada vez mais frequente sistematização e individualização das disciplinas

${ }^{14}$ FALCON Y TELLA, Maria José. Lições de teoria geral do Direito. São Paulo: Revista dos Tribunais, 2011, p. 122-123.

15 Embora seja perfeitamente possível que no âmbito doutrinário também sejam discutidas questões zetéticas (justificações, legitimidade, efetividade, análises sociológicas/antropológicas/políticas etc.), nesse ramo do conhecimento prepondera o aspecto dogmático. Nesse sentido: FERRAZ JR. Tercio Sampaio. Introdução ao estudo do direito: técnica, decisão, dominação. 4. ed. São Paulo: Atlas, p. 48.

${ }^{16}$ FERRAZ JR. Tercio Sampaio. Introdução ao estudo do direito: técnica, decisão, dominação, p. 48 
BAINY, André Kabke. Prospecções acerca do atual cenário do conhecimento jurídico: um estudo de caso na opinião de estudantes da faculdade de direito da Universidade Federal de Pelotas/RS. Revista Eletrônica Direito e Política, Programa de Pós-Graduação Stricto Sensu em Ciência Jurídica da UNIVALI, Itajaí, v.11, n.3, 30 quadrimestre de 2016. Disponível em: www.univali.br/direitoepolitica - ISSN 1980-7791.

(fragmentação, distribuição em "nichos do conhecimento"), o resultado frequentemente obtido é o descolamento da produção doutrinária em relação ao próprio sistema jurídico e à realidade social. Assim:

É preciso reconhecer que, nos dias atuais, quando se fala em Ciência do Direito, no sentido do estudo que se processa nas Faculdades de Direito, há uma tendência em identificá-la com um tipo de produção técnica, destinada apenas a atender às necessidades do profissional (o juiz, o promotor, o advogado) no desempenho imediato de suas funções. Na verdade, nos últimos cem anos, o jurista teórico, pela sua formação universitária, foi sendo conduzido a esse tipo de especialização, fechada e formalista ${ }^{17}$.

Acerca da mencionada fragmentação do conhecimento jurídico, Cattoni de Oliveira, prefaciando a obra de Lúcio Antônio Chamon Junior, faz interessante apontamento no que tange ao crescente desuso da Teoria Geral do Direito. 0 autor questiona se haveria algum traço comum entre as diferentes disciplinas (Direito Civil, Direito Penal, Direito Administrativo, etc.) que pudessem consubstanciar princípios gerais aplicáveis a todos esses Direitos. Nesse sentido, reflete:

Ou cada um deles é tão específico, que chegam a ser, antes que Direito, Civil, Penal ou Administrativo? E de modo até mesmo a perverter as regras da gramática, fazendo do substantivo (Direito) o adjetivo, e do adjetivo (civil, penal ou administrativo) o substantivo ${ }^{18}$.

O especialismo é evidente. Perdeu-se o caráter de integralidade e sistematicidade do Direito.

Outro aspecto que convém ser apontado é o relacionado ao fenômeno da "simplificação" da literatura jurídica. Cada vez mais os manuais, coleções "esquematizadas", "sistematizadas", cursos jurídicos "de A a Z", resumos e etc.

${ }^{17}$ FERRAZ JR. Tercio Sampaio. Introdução ao estudo do direito: técnica, decisão, dominação, p. 48

18 OLIVEIRA, Marcelo Andrade Cattoni de. Prefácio. In: CHAMON JUNIOR, Lucio Antônio. Teoria geral do direito moderno: por uma reconstrução crítico-discursiva na alta modernidade. Rio de Janeiro: Lumen Juris, 2007, p. xxix. 
BAINY, André Kabke. Prospeç̧ões acerca do atual cenário do conhecimento jurídico: um estudo de caso na opinião de estudantes da faculdade de direito da Universidade Federal de Pelotas/RS. Revista Eletrônica Direito e Política, Programa de Pós-Graduação Stricto Sensu em Ciência Jurídica da UNIVALI, Itajaí, v.11, n.3, 30 quadrimestre de 2016. Disponível em: www.univali.br/direitoepolitica - ISSN 1980-7791.

se tornam comuns, não apenas para quem visa ao estudo para concursos públicos e certames similares, mas também pelos estudantes da graduação, pósgraduação e profissionais do Direito.

Em uma rápida busca realizada na página virtual da Livraria Saraiva ${ }^{19}$, foi possível verificar que dentre os 45 livros jurídicos mais vendidos pelo portal, 23 se enquadram nessa categoria.

Sem pretender uma generalização, o cenário demonstra não haver estímulo à elaboração de doutrinas de fôlego. Salvo casos excepcionais, não se vê autores ganhando reconhecimento por uma vida acadêmica e obra consistentes. A doutrina perde cada vez mais espaço em razão da sua própria inércia - seja esta decorrente de sua própria incapacidade ou do contexto mercadológico que o conhecimento jurídico está submerso.

Bastasse o especialismo que permeou a doutrina de modo a deixá-la alheia à integridade da vida e do Direito, bem como a simplificação (simplismo) do material doutrinário que em regra vem sendo produzido, há que se apontar, ainda, o descrédito que a mesma tem sofrido em tempos de decisionismo e protagonismo judicial, a ponto de corroborar afirmações como aquela sustentada por integrante do Superior Tribunal de Justiça, Min. Humberto Gomes de Barros, assim votando:

Não me importa o que pensam os doutrinadores. Enquanto for Ministro do Superior Tribunal de Justiça, assumo a autoridade da minha jurisdição. O pensamento daqueles que não são Ministros deste Tribunal importa como orientação. A eles, porém, não me submeto. Interessa conhecer a doutrina de Barbosa Moreira ou Athos Carneiro. Decido, porém, conforme minha consciência. Precisamos estabelecer nossa autonomia intelectual, para que este Tribunal seja respeitado. É preciso consolidar o entendimento de que os Srs. Ministros Francisco Peçanha Martins e Humberto Gomes de Barros decidem assim, porque pensam assim. E o ST]

19 Disponível em: http://busca.saraiva.com.br/pages/livros/direito?page=1\&order=bestselling. Acesso em: 28 set. 2015 às 14h08min. Ressalta-se que na mesma listagem outros 10 itens correspondiam a versões impressas de legislação (Códigos, Vade Mecum etc.), praticamente não se constatando obras doutrinárias propriamente ditas. 
BAINY, André Kabke. Prospeç̧ões acerca do atual cenário do conhecimento jurídico: um estudo de caso na opinião de estudantes da faculdade de direito da Universidade Federal de Pelotas/RS. Revista Eletrônica Direito e Política, Programa de Pós-Graduação Stricto Sensu em Ciência Jurídica da UNIVALI, Itajaí, v.11, n.3, 30 quadrimestre de 2016. Disponível em: www.univali.br/direitoepolitica - ISSN 1980-7791.

decide assim, porque a maioria de seus integrantes pensa como esses Ministros. Esse é o pensamento do Superior Tribunal de Justiça, e a doutrina que se amolde a ele. É fundamental expressarmos o que somos. Ninguém nos dá lições. Não somos aprendizes de ninguém. Quando viemos para este Tribunal, corajosamente assumimos a declaração de que temos notável saber jurídico - uma imposição da Constituição Federal. Pode não ser verdade. Em relação a mim, certamente, não é, mas, para efeitos constitucionais, minha investidura obriga-me a pensar que assim seja ${ }^{20}$.

A afirmação do Ministro parece incoadunável com qualquer perspectiva minimamente democrática da construção do conhecimento jurídico. Mas nela fica evidente a mencionada falta de crédito que a doutrina experimenta. Esse descrédito é em grande parte decorrente da "falta de coragem" dos juristas em relação à inovação, reflexão, densificação etc., sendo que, justamente em virtude do "medo", frequentemente passam apenas a reproduzir comentários enfadonhos e óbvios acerca de dada decisão de algum Tribunal brasileiro.

E sobre esses aspectos Lênio Luiz Streck faz interessantes provocações no sentido de que "a doutrina deve voltar a doutrinar", não podendo se "contentar com reproduções assépticas (ou adesísticas) daquilo que os tribunais decidem. Aliás, com raras exceções, a doutrina contenta-se em fazer compilações das decisões tribunalícias"²1.

Ao fazer tamanha crítica, Streck sustenta que ao ficar à mercê das decisões judiciais, a doutrina afasta qualquer possibilidade de avanço, haja vista que nesse contexto o direito passa a ser compreendido apenas como aquilo que o judiciário disser que ele é. Indo além, afirma que:

[...] isso é correr o risco, mormente no direito, de dar espaço para a mediocretização do ensino e da escrita sobre

\footnotetext{
${ }^{20}$ Excerto do voto proferido pelo Ministro Humberto Gomes de Barros no julgamento do Agravo Regimental nos Embargos de Divergência em Recurso Especial no 279.889-AL [2001/01540593], em acórdão da Primeira Seção do Superior Tribunal de Justiça julgado em 14 ago. 2002

${ }^{21}$ STRECK, Lenio Luiz. Juízes devem fazer ou usar a doutrina só na hora do lazer? Revista Consultor Jurídico, São Paulo, ed. $1^{\circ}$ jan. 2015, disponível em http://www.conjur.com.br/2015jan-01/senso-incomum-juizes-usar-doutrina-somente-hora-lazer>. Acesso em 28 set. 2015, às $14 \mathrm{~h} 20 \mathrm{~min}$.
} 
BAINY, André Kabke. Prospeç̧ões acerca do atual cenário do conhecimento jurídico: um estudo de caso na opinião de estudantes da faculdade de direito da Universidade Federal de Pelotas/RS. Revista Eletrônica Direito e Política, Programa de Pós-Graduação Stricto Sensu em Ciência Jurídica da UNIVALI, Itajaí, v.11, n.3, 30 quadrimestre de 2016. Disponível em: www.univali.br/direitoepolitica - ISSN 1980-7791.

e do direito. Quanto mais deixarmos de lado a doutrina sofisticada ou a ela dermos pouca importância, mais daremos espaço para que os néscios invadam esse espaço e, perdendo a timidez, metam-se a escrever sobre qualquer coisa. Aliás, se examinarmos alguns livros que surgiram nos últimos tempos destinados a concursos públicos tratando das "disciplinas humanistas", constataremos que isso já aconteceu (é o Walking Dead do Direito). Já escrevi muito sobre isso. Eles acaba(ra)m com Kelsen, Hart, Rawls, chutam acerca do que é positivismo, massacram Kant e até mesmo nos temas dogmáticos um pouco mais sofisticados eles não conseguem passar da primeira raia. Sem contar o que fazem com a filosofia do direito e a hermenêutica. Insisto: se enfraquecermos a doutrina, estaremos facilitando a nesciontologia, novo "paradigma" em que o Direito é ensinado e discutido com a profundidade dos calcanhares de uma formiga (anã) ${ }^{22}$.

Temos uma doutrina que em regra não traz inovações, tampouco aprofunda as reflexões já existentes, deixando de integrar o conhecimento jurídico a todo o pensamento sistemático do Direito; e que se contenta em ser simplificada e muitas vezes reduzida a comentários expositivos de jurisprudência selecionada.

E, dada a sua afirmada importância, essa circunstância se revela deveras problemática.

Se por um lado se sabe que esse fenômeno decorre em grande parte da influência que os interesses econômicos havidos no mercado editorial e dos concursos públicos, por outro não há como se negar que tal fenômeno também decorra do empobrecimento epistemológico que o Direito experimenta, conforme continuamente afirmado no presente estudo.

Portanto, também nesse ponto a crise epistemológica enfrentada pelo Direito ganha relevância e necessidade de atenção: a baixa qualidade doutrinária, assim como um sangramento que precisa ser estancado, assemelha-se muito mais a um sintoma do que à causa propriamente dita.

22 STRECK, Lenio Luiz. Juízes devem fazer ou usar a doutrina só na hora do lazer? Revista Consultor Jurídico, São Paulo, ed. 10 jan. 2015, disponível em http://www.conjur.com.br/2015jan-01/senso-incomum-juizes-usar-doutrina-somente-hora-lazer>. Acesso em 28 set. 2015, às $14 \mathrm{~h} 20 \mathrm{~min}$. 
BAINY, André Kabke. Prospecções acerca do atual cenário do conhecimento jurídico: um estudo de caso na opinião de estudantes da faculdade de direito da Universidade Federal de Pelotas/DC Revista Eletrônica Direito e Política, Programa de Pós-Graduação Stricto Sensu em Ciência Jurí

da UNIVALI, Itajaí, v.11, n.3, 30 quadrimestre de 2016. Disponível em: www.univali.br/direitoepolitica - ISSN 1980-7791.

\section{CONSIDERAÇÕES FINAIS}

As informações colhidas ao longo da presente pesquisa corroboram a afirmação de que os debates jurídicos mais complexos sempre trazem consigo aspectos fundamentais ao próprio Direito - as chamadas questões zetéticas -, e que, quando esses aspectos são deixados de lado na discussão, o resultado comum é uma insuficiência argumentativa e a não obtenção de soluções.

Essa insuficiência é resultado de uma visão fragmentada do conhecimento jurídico e do próprio mundo da vida: o conhecimento, cada vez mais raso e compartimentado, não tem mais dado conta da complexidade contemporânea.

Tal problemática, além de revelar-se insuficiente à obtenção de respostas aos problemas jurídicos, acarreta uma baixa qualidade no ensino jurídico e uma baixa qualidade na literatura jurídica (Doutrina).

Verificou-se, todavia, que embora grande parte dos acadêmicos respondentes concorde com esse ponto de vista que defende a imprescindibilidade das disciplinas propedêuticas - fato a ser comemorado e explorado na academia -, é evidente o desprestígio que tais disciplinas enfrentam.

Constatou-se que isso se dá em virtude de que as disciplinas teóricas apresentam uma realidade e razão bastante abstratas, o que acaba ensejando o desinteresse dos estudantes. Com efeito, o jurista não é preparado para pensar o Direito a partir de suas bases, mas, sim, apenas a partir das suas consequências remediais/pontuais (que são aquelas incidentes na sociedade de forma palpável).

Essa contradição - de por um lado reconhecer a importância, mas por outro não fazer questão de usufruí-la - revela uma inércia que acomete os estudantes, que passam a ser passivos e perdem o espírito crítico e investigativo do conhecimento.

Ocorre que as opiniões colhidas junto aos acadêmicos da Faculdade de Direito da Universidade Federal de Pelotas apontam que os próprios respondentes reconhecem a importância das discussões teóricas, das disciplinas propedêuticas 
BAINY, André Kabke. Prospecções acerca do atual cenário do conhecimento jurídico: um estudo de caso na opinião de estudantes da faculdade de direito da Universidade Federal de Pelotas/RS. Revista Eletrônica Direito e Política, Programa de Pós-Graduação Stricto Sensu em Ciência Jurídica da UNIVALI, Itajaí, v.11, n.3, 30 quadrimestre de 2016. Disponível em: www.univali.br/direitoepolitica - ISSN 1980-7791.

e da necessidade de se considerar o Direito enquanto fenômeno integral (e não fragmentado, na contramão cultural contemporânea).

Isso se mostra fundamental à continuidade das investigações correlatas, pois realoca o problema do conhecimento jurídico às questões de fundo (epistemológicas) - e, por conseguinte, distanciando-se daquelas que pretendem discutir apenas a relação ensino-aprendizagem, a doutrina, a precarização dos cursos jurídicos etc.

\section{REFERÊNCIAS DAS FONTES CITADAS}

BRASIL. Superior Tribunal de Justiça. Agravo Regimental nos Embargos de Divergência em Recurso Especial no 279.889-AL (2001/0154059-3). Relator: Ministro Francisco Peçanha Martins. Acórdãos, 14 agosto 2002. Disponível em: <https://ww2.stj.jus.br/processo/pesquisa/>. Acesso em: 28 set. 2015.

BRASIL. Supremo Tribunal Federal. Arguição de Descumprimento Fundamental no 132. Relator: Ministro Ayres Britto. Acórdãos, 05 maio 2011. Disponível em: http://www.stf.jus.br/portal/processo/verProcessoAndamento.asp?incidente $=259$ 8238. Acesso em 29 set. 2015.

BRASIL. Supremo Tribunal Federal. Ação Direta de Inconstitucionalidade 4277. Relator: Ministro Ayres Britto. Acórdãos, 05 maio 2011. Disponível em: <http://www.stf.jus.br/portal/processo/verProcessoAndamento.asp?incidente $=1$ $1872>$. Acesso em 29 set. 2015.

FALCON Y TELLA, Maria José. Lições de teoria geral do Direito. São Paulo: Revista dos Tribunais, 2011.

FERRAZ JR., Tercio Sampaio. Introdução ao estudo do direito. São Paulo: Atlas, 2003.

LAKATOS, Eva Maria e MARCONI, Marina de Andrade. Fundamentos da metodologia científica. São Paulo: Atlas, 2010.

LAKATOS, Eva Maria e MARCONI, Marina de Andrade. Metodologia Científica. São Paulo: Atlas, 1992.

LIPOVESTKY, Gilles. Os tempos hipermodernos. São Paulo: Barcarolla, 2004. 
BAINY, André Kabke. Prospecções acerca do atual cenário do conhecimento jurídico: um estudo de caso na opinião de estudantes da faculdade de direito da Universidade Federal de Pelotas/RS. Revista Eletrônica Direito e Política, Programa de Pós-Graduação Stricto Sensu em Ciência Jurídica da UNIVALI, Itajaí, v.11, n.3, 30 quadrimestre de 2016. Disponível em: www.univali.br/direitoepolitica - ISSN 1980-7791.

OLIVEIRA, Marcelo Andrade Cattoni de. Prefácio. In: CHAMON JUNIOR, Lúcio Antônio. Teoria geral do direito moderno: por uma reconstrução criticodiscursiva na alta modernidade. Rio de Janeiro: Lumen Juris, 2007.

ORDEM DOS ADVOGADOS DO BRASIL. Brasil, sozinho, tem mais faculdades de Direito que todos os países. Disponível em: <http://www.oab.org.br/noticia/20734/brasil-sozinho-tem-mais-faculdades-dedireito-que-todos-os-paises. > Acesso em: 25 set 2015, às 16h04min.

ORDEM DOS ADVOGADOS DO BRASIL. OAB Ensino Jurídico: balanço de uma experiência. Brasília: OAB, 2000.

STRECK, Lenio Luiz. Juízes devem fazer ou usar a doutrina só na hora do lazer? Revista Consultor Jurídico, São Paulo, Ed. $1^{\circ}$ jan. 2015. Disponível em: < http://www.conjur.com.br/2015-jan-01/senso-incomum-juizes-usar-doutrinasomente-hora-lazer>. Acesso em 28 set. 2015, às 14h20min. 
BAINY, André Kabke. Prospecções acerca do atual cenário do conhecimento jurídico: um estudo de caso na opinião de estudantes da faculdade de direito da Universidade Federal de Pelotas/RS. Revista Eletrônica Direito e Política, Programa de Pós-Graduação Stricto Sensu em Ciência Jurídica da UNIVALI, Itajaí, v.11, n.3, 30 quadrimestre de 2016. Disponível em: www.univali.br/direitoepolitica - ISSN 1980-7791.

Apêndice A - Questionário aplicado aos respondentes dos 10, $3^{\circ}$ e $6^{\circ}$ anos da Faculdade de Direito da Universidade Federal de Pelotas - UFPel, em junho de 2015.

1) Ao pensar em "direito", o que vem de imediato em sua mente?
(a) lei
(b) justiça
(c) ordem
(d) Estado
(e) sociedade
(f) outro (qual?)

2) Ao pensar sobre os problemas jurídicos (quaisquer que sejam, como por exemplo falta de efetividade, ilegitimidade etc.), para você qual é o principal fator determinante para o surgimento/perpetuação de tais problemas?
a) baixa qualidade legislativa;
b) má formação dos profissionais do direito;
c) falta de uma correta compreensão dos institutos jurídicos (baixa qualidade da doutrina);
d) exagerada liberdade e poder aos juízes, que acabam decidindo de acordo com "suas próprias cabeças".
e) falta de compreensão do fenômeno jurídico como um todo, o que leva à desconexão do direito com outras áreas da vida;
f) falta de compreensão do que seja o Direito propriamente dito, e do que ele deve corresponder na sociedade.

3) Dentre as seguintes disciplinas que compõe o currículo do ensino jurídico, estabeleça, pelo seu ponto de vista, a ordem de importância ("1" para a mais importante até "16" para a menos importante): 
BAINY, André Kabke. Prospecções acerca do atual cenário do conhecimento jurídico: um estudo de caso na opinião de estudantes da faculdade de direito da Universidade Federal de Pelotas/RS. Revista Eletrônica Direito e Política, Programa de Pós-Graduação Stricto Sensu em Ciência Jurídica da UNIVALI, Itajaí, v.11, n.3, 30 quadrimestre de 2016. Disponível em: www.univali.br/direitoepolitica - ISSN 1980-7791.

( ) Direito Constitucional

( ) Direito Administrativo

( ) Direito Empresarial

( ) Direito Civil

( ) Direito Penal

( ) Direito do Trabalho

( ) Direito Processual Civil

( ) Direito Processual Penal

( ) Direito Tributário

( ) Laboratório de Prática Jurídica

( ) Serviço de Assistência Judiciária

( ) Introdução ao Direito

( ) Filosofia do Direito/Hermenêutica

( ) Sociologia/Antropologia Jurídica

( ) Psicologia Jurídica

( ) Teoria do Estado, Política e Direito (TEPD)

4) Dentre as seguintes disciplinas que compõe o currículo do ensino jurídico, estabeleça a sua ordem de preferência ("1" para a mais interessante/preferida até "16" para a menos interessante):

( ) Direito Constitucional

( ) Direito Administrativo

( ) Direito Empresarial

( ) Direito Civil

( ) Direito Penal

( ) Direito do Trabalho

( ) Direito Processual Civil

( ) Direito Processual Penal

( ) Direito Tributário

( ) Laboratório de Prática Jurídica

( ) Serviço de Assistência Judiciária

( ) Introdução ao Direito 
BAINY, André Kabke. Prospecções acerca do atual cenário do conhecimento jurídico: um estudo de caso na opinião de estudantes da faculdade de direito da Universidade Federal de Pelotas/RS. Revista Eletrônica Direito e Política, Programa de Pós-Graduação Stricto Sensu em Ciência Jurídica da UNIVALI, Itajaí, v.11, n.3, 30 quadrimestre de 2016. Disponível em: www.univali.br/direitoepolitica - ISSN 1980-7791.

( ) Filosofia do Direito/Hermenêutica

( ) Sociologia/Antropologia Jurídica

( ) Psicologia Jurídica

( ) Teoria do Estado, Política e Direito (TEPD)

5) Dentre as seguintes atividades educacionais possíveis, estabeleça, pelo seu ponto de vista, a ordem de importância ("1" para a mais importante até " 6 " para a menos importante):

( ) Ensino (aulas expositivas propriamente ditas)

( ) Pesquisa (seja individual, seja em grupos de estudo)

( ) Extensão (projetos como o Defensa, por exemplo)

( ) Serviço de Assistência Judiciária

( ) Estágio(s) em Direito

( ) Participação em eventos, palestras, congressos etc.

6) Na sua opinião, as disciplinas propedêuticas (especificamente introdução ao direito, filosofia do direito e hermenêutica) são importantes porque:

a) passaram a ser exigidas em concursos públicos/exame da $O A B$;

b) dão ao jurista um espírito crítico;

c) aumentam o senso de humanidade e/ou justiça na formação do jurista;

d) aumentam a capacidade de compreensão do próprio direito e do mundo como um todo;

e) não são importantes.

Submetido em: julho/2016

Aprovado em: setembro/2016 